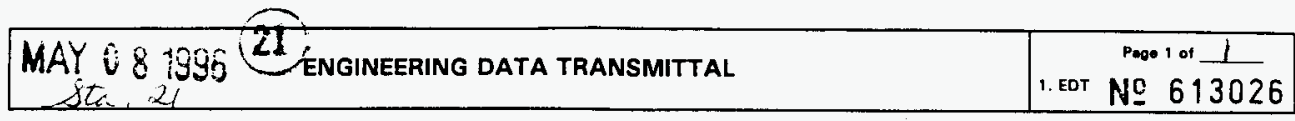

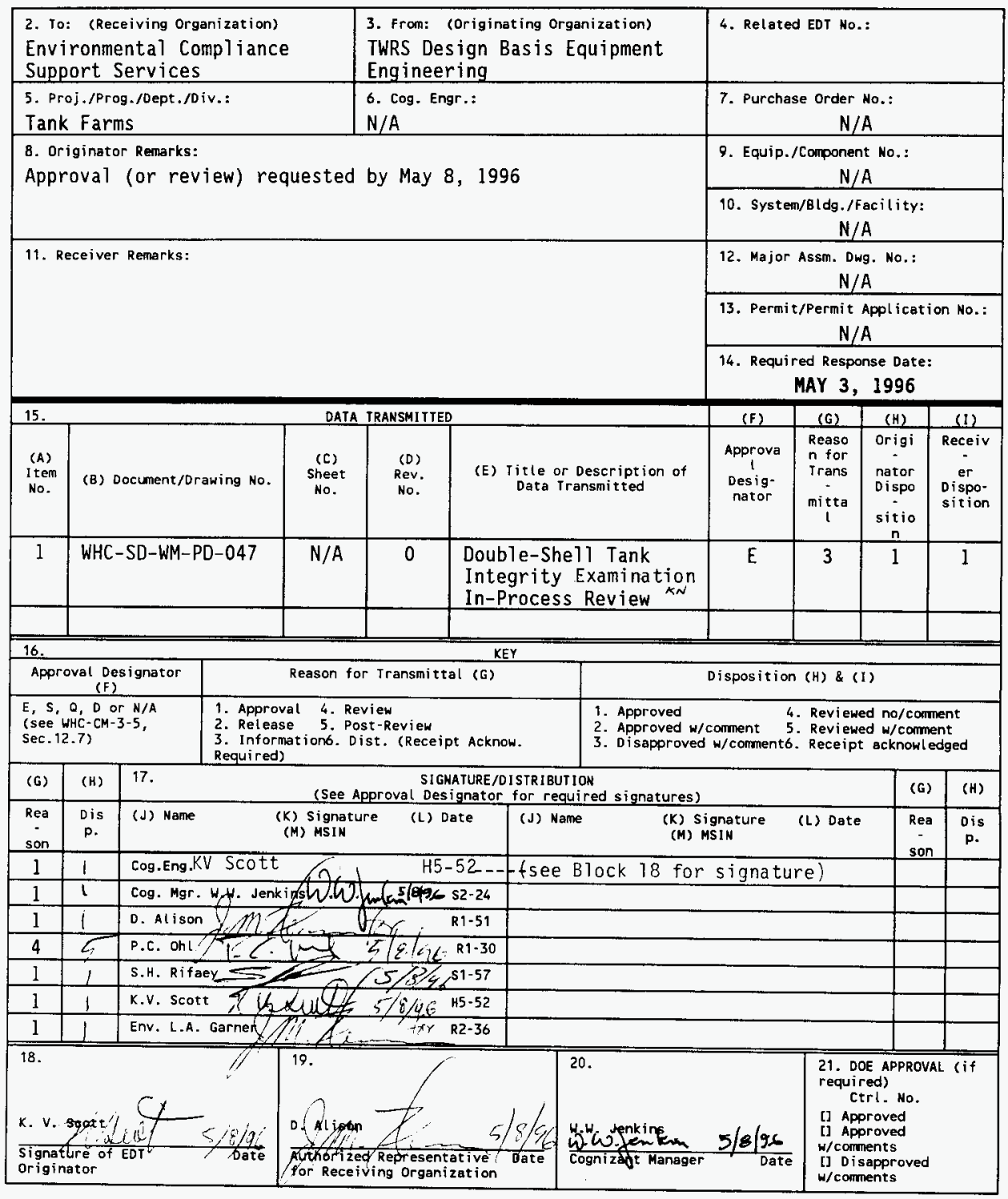

6D-7400-172-2(04/94) GEF097 


\section{Double-Shell Tank Integrity Examination In-Process Review}

\section{K. V. Scott}

Westinghouse Hanford Company, Richland, WA 99352

U.S. Department of Energy Contract DE-AC06-87RL10930

$\begin{array}{lll}\text { EDT/ECN: } & 613026 & \text { UC: } 2030 \\ \text { Org Code: } & 74 F 10 & \text { Charge Code: } \\ \text { B\&R Code: } & \text { EW31530071 } & \text { Total Pages: } \\ 22 \\ \mathrm{KN}\end{array}$

Key Words: Double-Shell Tank, Integrity Examination, In-Service Inspection, U1trasonic Testing, Corrosion, Pitting, Stress-Corrosion Cracking, Inspection Equipment

Abstract: This document provides a technical basis for performing an examination of the DSTs; the scope of the examination; the equipment capable of completing the examination and the method selected for performing the examination.

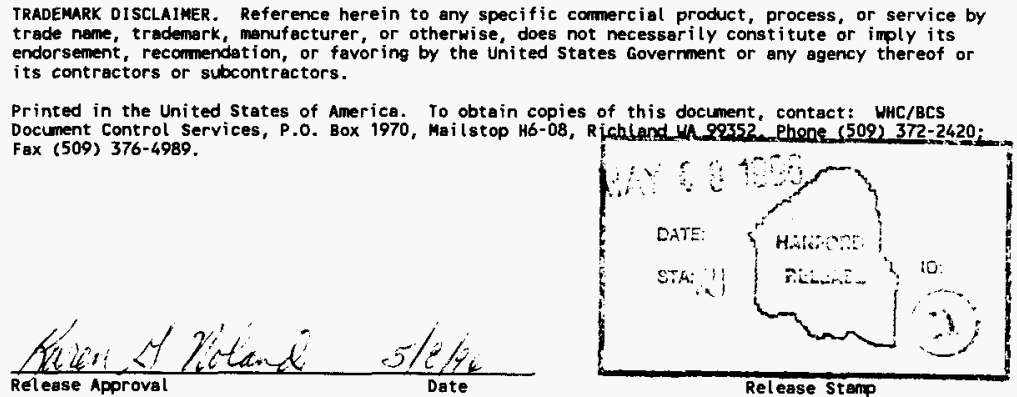

\section{Approved for Public Release}




\section{CONTENTS}

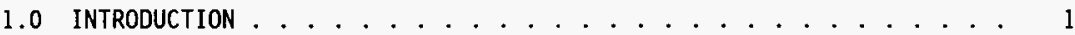

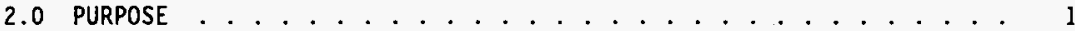

3.0 BASIS FOR THE INTEGRITY EXAMINATION ............. I I

3.1 INTEGRITY EXAMINATION PERFORMANCE ............ $\ldots$

3.2 INTEGRITY EXAMINATION SCOPE AND CRITERIA . . . . . . . . . 3

3.2.1 Aging Degradation Processes . . . . . . . . . 3

3.2 .2 Measurements . . . . . . . . . . . . . 3

3.2 .3 Regions and Extent of Examination . . . . . 4

3.3 INTEGRITY EXAMINATION METHODS ............ 5

3.4 INTEGRITY EXAMINATION EQUIPMENT . . . . . . . . . . . 7

4.0 RECOMMENDED AlteRnATIVE . . . . . . . . . . . . . . . 9

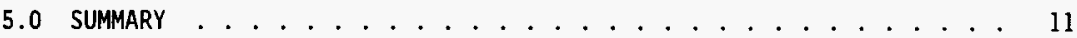

6.0 REFERENCES ....................... 11

APPENDIX A COST-BENEFIT EVALUATION ............. A-i 
WHC-SD-WM-PD-047

Rev. 0

\section{LIST OF TABLES}

1. Flaw Characterization Requirements

2. Cost and Schedule Summary for DSTI 
Rev. 0

\section{DOUBLE-SHELL TANK INTEGRITY EXAMINATION IN-PROCESS REVIEW}

\subsection{INTRODUCTION}

Examining the condition of critical components using in-service testing or inspection is an accepted practice for ensuring that the components can be relied on for continued operation. In-service testing is one of the activities prescribed in the plan to assess the condition of the double-shell tank (DST) systems (Walter 1995). Because the DSTs are the most critical components in the waste system, a specific plan (Pfluger 1994a) and inspection criteria (Bandyopadhyay 1994) were prepared, and special equipment is being developed to examine the primary tank (inner shell) and secondary tank (outer she11) liners of the 28 DSTs on the Hanford Site. This document provides an in-process review and basis for the DST integrity examination activities.

\subsection{PURPOSE}

This document explains to stakeholders the bases for the following:

- Performing integrity examination of the DSTs (excluding ancillary equipment)

- The scope of the examination

- The method selected for performing the examination

- The selection of examination equipment.

\subsection{BASIS FOR THE INTEGRITY EXAMINATION}

\subsection{INTEGRITY EXAMINATION PERFORMANCE} follows:

The two principal reasons to perform the integrity examinations are as

- Waste storage capability will be needed throughout the waste remediation period

- Regulatory requirements are in place for dangerous waste storage tanks.

The most recent information shows that waste in the Tank Waste Remediation System current baseline can be managed using the existing waste tank capacity through fiscal year 2003 (Koreski et a1. 1995, Jensen 1995a). This conclusion relies on the continued integrity of the DSTs. Tank failure would reduce the available tank storage capacity and adversely affect waste management options. 
In support of studies assessing the need for new tanks, analyses have been performed to estimate the remaining 1 ife of the existing DSTs (Schwenk 1995, Abatt 1996). The analyses concluded that, al though the tanks would very 1 ikely continue to perform without failure at least until 2005, lack of information about the current condition of the tanks makes this estimate uncertain. When the first DSTs were put in service in 1968, waste chemistry and temperature limits were established to preclude excessive degradation of the carbon steel tank by corrosion (uniform corrosion, pitting, and stresscorrosion cracking). Short-duration laboratory tests and 1 imited experience were used to establish these limits (Divine 1983, 1984a, 1984b, 1984c, 1985).

Integrity examinations provide information on the current condition of the tanks. This information can be used to judge which tanks have the most remaining useful 1 ife. The information may also be useful for adjusting corrosion control measures to gain additional tank life ( $\mathrm{Nel}$ son et al. 1996) and avoid early failure.

The regulatory bases for integrity assessments are established by the Resource Conservation and Recovery Act of 1976 to provide industry with incentives to contain waste and protect the environment. The U.S. Environmental Protection Agency (EPA) regulates waste tank systems in accordance with those 1 aws. The EPA allows the Washington State Department of Ecology (Ecology) to regulate waste tank systems in Washington State in accordance with the Washington Administrative Code (WAC 173-303), which is consistent with EPA regulations ( 40 Code of Federal Regulations [CFR] 265) for waste tank systems.

The U.S. Department of Energy (DOE) has agreed to operate the Hanford Site in accordance with the regulations of WAC 173-303 for dangerous waste and WAC 173-303-640 for dangerous waste tank systems. This agreement is described in the Hanford Federal Facility Agreement and Consent Order (Tri-Party Agreement) (Ecology et al. 1996). The latest revision of the Tri-Party Agreement requires a DST waste system integrity assessment be done in accordance with WAC 173-303-640 by September 30, 1999 or at a later date determined by negotiation with Ecology. The integrity assessment will be included in the Part B Permit Application for the Hanford Site's 28 DSTs.

Integrity examinations are needed to support and validate corrosion assessments that are an essential part of the integrity assessment required by state regulations. Corrosion assessments consider the structural materials, their condition, and waste chemistry (past and projected). The results of a corrosion assessment could, for example, indicate the following:

- Severe pitting near the waste-vapor interface region of a primary tank wal1, which necessitates a future 1 imit on that tank's allowable waste volume

- Crack growth rates that dictate the need for alternative storage capacity. The growth rates can be used to predict when alternative storage capacity needs to be made available. 
WHC-SD-WM-PD-047

Rev. 0

\subsection{INTEGRITY EXANINATION SCOPE AND CRITERIA}

The purpose of the integrity examinations is to obtain adequate information so that rational judgements of material conditions can be made. The scope of the examination as outlined is judged to be adequate to obtain this information. The scope may change, depending on what is found during the examination.

The high-level waste storage tanks are used to confine the liquid, salt cake, and sludge waste so that it does not enter the environment. The tanks do this by remaining leak tight and displaying structural stability. Regardless of their compliance with design considerations, their continued performance depends on how well they resist the aging process.

\subsubsection{Aging Degradation Processes}

Blackburn (1992) pointed out that the major cause of DST material degradation is waste-induced corrosion. Waste-induced corrosion can generally appear as pitting corrosion, stress-corrosion cracking (SCC), and wall thinning (uniform corrosion). If pitting corrosion and wall thinning have occurred, they are more likely to be found at waste boundaries (vapor-liquid, liquid-sludge), around weldments, and under bottom-lying deposits. SCC is more likely to be found at regions under high stress, such as the bottom knuckle in proximity to the circumferential weldment located at the juncture with the bottom plate. The most detrimental location for any form of degradation would be the tank bottom. Any leakage here would result in removing the tank from service.

\subsubsection{Measurements}

Material degradation is detected as geometric changes caused by thinning of a wall, growth of pits, or propagation of cracks. Once these defects are detected, subsequent inspections for increases in their dimensions will be used to determine the rate of degradation in the primary and secondary tanks. These examinations will also provide a basis to improve in-tank practices to minimize corrosion. Measurements of wall thickness, pitting corrosion, and SCC must be thorough enough so that these defects can be detected before they become threaten the leak tightness of the primary tank or the secondary tank. Also, to estimate the rate of wall penetration, the measurements must be precise enough to detect changes in the size of the defects during subsequent examinations.

The minimum dimension and accuracy for wall thinning, pitting corrosion, and SCC, that the examination equipment must characterize, are shown in Table 1 (Pfluger 1995). Equipment that can meet these requirements will be able to detect significant defects (depths of 20 to 50 percent of the wall thickness). 
Table 1. Flaw Characterization Requirements.

\begin{tabular}{|l|c|c|}
\hline \multicolumn{1}{|c|}{ Condition } & $\begin{array}{c}\text { Minimum Dimension } \\
\text { to be Characterized }\end{array}$ & Accuracy (in.) \\
\hline \hline Wall thinning & none & \pm 0.0025 \\
\hline Pitting Corrosion & $0.7 \mathrm{t}$ diam. $\times 0.35 \mathrm{t}$ deep ${ }^{2}$ & \pm 0.020 \\
\hline $\begin{array}{l}\text { SCC (axial and } \\
\text { circumferential) }\end{array}$ & $\begin{array}{c}\mathrm{t} \text { long } \times 0.5 \mathrm{t} \text { deep } \\
\text { in. long } \times 0.2 \mathrm{t} \text { deep }\end{array}$ & $\begin{array}{c} \pm 0.050 \text { (depth) } \\
\pm 0.5 \text { (length) }\end{array}$ \\
\hline
\end{tabular}

'Nominal tank wall thickness is $t$.

${ }^{2}$ Pits are on the tank inside surface and are assumed to be hemispherical.

The next step in establishing the basis for the integrity examination scope is to identify the regions of the tanks to be examined and the extent of the examination.

\subsubsection{Regions and Extent of Examination}

The examinations are performed to detect global degradation, not localized degradation at a unique material weakness. Examination will not reliably find the localized degradation. Ultimately, detection of severe localized degradation will be accomplished by the leak detection system.

Global degradation poses a greater threat to tank storage capacity because it may be a degradation process common to several tanks. The potential for satisfactorily reducing this threat is high because integrity examination can detect global degradation.

The regions to be examined are the locations where the aging degradation processes are most likely to occur (see Section 3.2.1). The examination in all regions is for wall thinning and pits. Only in the higher stress regions of the primary tank-the lower wall and knuckle-are examinations for cracks required. The examination will be thorough enough to judge the tank integrity. In large commercial industries (nuclear, oil, and chemical) the extent of examination is determined by experience and consensus and becomes an industry standard. No industry standard has been established for underground radioactive waste storage tanks. However, an expert panel (Bandyopadhyay 1994) was assembled to determine an appropriate sample size based on the relative seriousness of a threat posed by a leaking nuclear component, an oil tank, and a chemical tank. The panel determined that a 5-percent sample in each of the critical regions in 10 percent of the tank population would be adequate.

The tank population sample of 10 percent assumes that all tanks in the population are similar with respect to aspects of their design and corrosion service. Westinghouse Hanford Company (WHC) has determined that examining six DSTs (a $20 \%$ sample) is sufficient for the initial assessment of the condition 
of all 28 DSTs (Pfluger 1994b). The DSTs were selected based on the following variables (Bandyopadhyay et a). 1994, Schwenk and Scott 1996):

- Tank age, based on date of first fluid entry

- Waste temperature

- Levels of corrosion inhibitors

- Deviation from normal behavior, i.e., changes in sludge levels, hydrogen release and waste transfers

- Least waste depth fluctuation

- Tank steel type

- Chemical species that could activate SCC

- Waste type.

Any examination findings that exceed the acceptance criteria (Jensen 1995b) will result in a reassessment of the scope (i.e., location, areas, and extent) of the planned examinations. Each tank al so will be evaluated to determine whether their condition calls for continued service, repair, or replacement.

\subsection{INTEGRITY EXAMINATION METHODS}

This section identifies the examination methods in use, those planned for use, and those having potential for use. All are reviewed periodically to ensure that the most effective method is used.

- Visual Examination. Visual examination is the most common and effective method for assessing general corrosion degradation. Remote visual examinations in the annulus between the primary tank and secondary tank 1 iner have been completed for a 1128 DSTs (Walter 1992a, 1992b; Harris 1993a, 1993b, 1993c). These visual examinations did not reveal any significant annulus-side corrosion, primary tank leakage, or gross shape change of either the primary tank or secondary tank material.

A variation of the visual examination of the tank is visual examination of equipment exposed to the waste and other conditions inside the tank. If the equipment and tank are made of the same material, visual examination can be useful for estimating uniform corrosion and pitting as a function of waste depth in a DST. The equipment will have been exposed to an environment similar to that of the tank walls and bottom, particularly if the equipment and the tank are about the same age.

- Radiography. Requires placement of film and exposing the film to a film-sensitive energy. The method does not provide accurate defect size information under the best of circumstances. The 
nonuniform and excessive radiation from the tank waste would interfere with the collection of data.

- Eddy Current Testing. In carbon steel this method has seen limited application and only detects shallow defects at or near the surface. To perform an eddy current examination would require access to the inside surface of the tank and emptying the tank and cleaning the surface. The method cannot be used to measure the wall thickness.

- Acoustic Emission. A useful method most commonly used in the Taboratory to detect sound emanating from a growing crack. It has no sizing capability and cannot detect pits, wall thinning, or static cracks. This method has no satisfactory calibration standards.

- Magnetic Flux Leakage (MFL). MFL has been used to inspect gastransmission pipelines. The MFL tools have systems for magnetizing, sensing, data recording, and power. MFL can generally detect metal-loss corrosion, but not cracks. The accuracy of characterizing the geometry of metal-loss regions is not well known. Loose corrosion and mill scale should be removed from surfaces to be examined to maintain a consistent distance between the sensor(s) and the material surface. A large force would be required to overcome the magnetic attraction and move the sensor across the inspection surface. High pressures are used to move MFL tools through gas-transmission pipelines.

- Alternating Current Field Measurement (ACFM). ACFM is being developed for the light-duty utility arm to perform NDE inside large waste tanks (e.g. single-shell tanks, DSTs) for corrosion pitting and cracks. ACFM is an electromagnetic technique. It induces a uniform $A C$ field in the material and measures the magnetic fields above it while passing over but not touching the material. This technology was not developed to meet the flaw characterization requirements for integrity examinations, however any information obtained from DSTs should be reviewed to possibly augment the integrity examination of DSTs. Plans to certify this method are being made.

- Electromagnetic-acoustic transducers (EMATs). These could be used in place of the piezoelectric transducers normally used for ultrasonic testing (UT). EMATs have several advantages over the piezoelectric transducers. They require no couplant, can easily excite shear waves propagating normal to surfaces, and are less influenced by the presence of surface scale and roughness. The technical trade-off is a considerably lower efficiency, necessitating the use of specially designed electronics. Adequate reliability is yet to be established.

- U1trasonic Examination. UT is a widely used volumetric examination method capable of measuring wall thickness and pit and crack depth to within 0.010 in. or better, depending on the system design. Remote systems are routinely used in special nuclear 
applications. If wall thinning, pits, or cracks are detected, estimates of the time remaining to wall penetration can be made by estimating the rate of wall penetration from the number of years of service and the defect size. Examinations in the same area after additional service can be used to more accurately determine the rate of wall penetration. Sufficient testing is performed to demonstrate the repeatability and accuracy of the measurements.

WHC reviewed the UT capabilities. Many sources of ultrasonic expertise, both in industry and at other government facilities, were consulted for their ideas and experience. The DOE sponsored Tank Structural Intergity Panel (TSIP) reviewed and commented on UT as an examination activity. They concluded that information provided by UT would determine the current condition of the tanks, allow estimates to be made of their usable service life, and determine the adequacy of the current corrosion control practices (Bandyopadhyay et al. 1994).

Based on the review, a combination of UT and visual examination has been selected as an acceptable method for performing the corrosion assessment portion of the DST integrity assessment.

\subsection{INTEGRITY EXAMINATION EQUIPMENT}

The DSTs do not include design features, other than inspection risers, that allow equipment access to examine the condition of the tank material. The radioactive and hazardous waste environment further restricts entry of any physical device that may be used for measuring material degradation.

For visual examinations, remotely operated equipment has been developed and used to perform direct visual examination of DST annuli (Wa1ter 1992a, $1992 b$, Harris 1993a, 1993b, 1993c). To perform in-tank visual examinations, existing equipment developed in support of other Tank Waste Remediation System (TWRS) programs can be used.

For the ultrasonic examinations, several equipment options exist that, with further development, could be used to examine the tank wall but not the tank bottom. Two criteria for the ultrasonic examination must be considered when determining equipment availability. First, the ultrasonic transducer assembly must be designed to meet the DST inspection requirements. The design and fabrication of this assembly is simple and inexpensive. Second, the transducer assembly must be in contact with the tank and must be movable in precise increments. Obtaining equipment that delivers the transducer assembly to the tank wall is not difficult. Obtaining equipment that delivers the assembly to the tank bottom and knuckle is a unique and more difficult task. Delivery equipment that can be used to examine the tank wall is available from two sources: the government and commercial vendors. Two government-owned equipment options are available. One uses a magnetic crawler to transport equipment on the tank wall and the other is a more complex mechanism, designed specifically to meet all the inspection requirements for DST ultrasonic examinations.

The only delivery equipment available for examining the tank bottom and lower knuckle is the government-owned DST inspection system. Magnetic 
crawlers are commercially available for examining above-ground tanks. These crawlers could be adapted for examining the walls of the DSTs, but not the bottom or lower knuckle. However, commercial components exist that, with relatively minor development and testing, could provide a tank bottom/knuckle examination system. One possible system would use a standard floor crawler with tools mounted on the crawler that would extend the transducer assembly from the floor of the tank annulus to the knuckle and bottom. Another would be a floor crawler mounted with the DST inspection system's tank bottom/knuckle examination tool. Examination of all the important tank areas (wall, bottom, and lower knuckle) could be accomplished with the DST inspection (DSTI) system. The DSTI system was developed, fabricated, and tested under a cost-plus contract and is intended to meet the requirements described in Section 3.2 .

The DSTI system was performance tested at the subcontractor's facility and several exceptions were taken by the contractor and also noted by the WHC representative administering the test. In addition to the exceptions, the DSTI system failed several times and had to be repaired so that testing could continue. The significant exceptions are related to the failure-mode recovery of the system from the annulus, overall system reliability, and meeting inspection requirements for the lower primary tank knuckle region. In addition, some enhancements are necessary to improve operational efficiency.

Preparations have been made at the Hanford Site to begin modifying the DSTI system. The mockup and deployment platform are complete. A contractor employee has unpacked the system. The contractor has been asked to stop work until further notice.

The cost and schedule to complete the DSTI system and perform inspections are provided in Table 2 along with estimates for the options already discussed. These estimates are provided to show the relative costs and schedule for the equipment options. The uncertainties in the estimates are not all equal. More information is provided in Section 4.0 to support a recommendation on ultrasonic examination equipment. 
Table 2. Cost and Schedule Summary for DSTI.

\begin{tabular}{|c|c|c|c|}
\hline Cost and schedule & Equipment & $\begin{array}{l}6 \text { DST } \\
\text { exams }\end{array}$ & Total \\
\hline $\begin{array}{l}\text { Cost: } \\
\text { DSTI } \\
\text { Magnetic Crawler (Government owned) } \\
\text { Magnetic Crawler (Purchase newer } \\
\text { government design) } \\
\text { Magnetic Crawler (Commercial) } \\
\text { Floor Crawler System (DSTI Tool) } \\
\text { Schedule: } \\
\text { DSTI } \\
\text { Magnetic Crawler (Government owned) } \\
\text { Magnetic Crawler (Purchase newer } \\
\text { government design) } \\
\text { Magnetic Crawler (Commercial) } \\
\text { Floor Crawler System (DSTI Tool) }\end{array}$ & $\begin{array}{l}\$ 1.2 \mathrm{M} \\
\$ 150 \mathrm{~K} \\
\$ 560 \mathrm{~K} \\
\mathrm{TBD}^{1} \\
\$ 200 \mathrm{~K} \\
18 \mathrm{mo} \\
3 \mathrm{mo} \\
10 \mathrm{mo} \\
10 \mathrm{mo} \\
12 \mathrm{mo}\end{array}$ & $\begin{array}{l}\$ 2.4 \mathrm{M} \\
\$ 1.1 \mathrm{M} \\
\$ 1.1 \mathrm{M} \\
\$ 1.1 \mathrm{M} \\
\$ 1.1 \mathrm{M} \\
12 \mathrm{mo} \\
6 \mathrm{mo} \\
6 \mathrm{mo} \\
6 \mathrm{mo} \\
6 \mathrm{mo}\end{array}$ & $\begin{array}{l}\$ 3.6 \mathrm{M} \\
\$ 1.3 \mathrm{M} \\
\$ 1.7 \mathrm{M} \\
-- \\
\$ 1.3 \mathrm{M} \\
30 \mathrm{mo} \\
9 \mathrm{mo} \\
16 \mathrm{mo} \\
16 \mathrm{mo} \\
18 \mathrm{mo}\end{array}$ \\
\hline
\end{tabular}

${ }^{1}$ No estimate is available. Some development by the supplier would be required.

\subsection{RECOMMENDED ALTERNATIVE}

To identify a set of integrity examinations that reduce the cost and the overall uncertainty, a cost/benefit evaluation was conducted of all the inspection requirements (see Appendix A). The results of such an evaluation depend on what is considered the most beneficial-a low project cost, a short schedule, or data quality.

The recommended alternative has the attributes of a low project cost and reduced data quality. The recommended alternative includes the following inspection activities:

- Visual examination of equipment as it is removed from the tank. Two different tanks are scheduled to have equipment removed in the next 18 months.

- Visual examination of the tank inside surface when the waste is removed during routine tank operations (evaporator campaigns). 
Three tanks will be examined. If successful, and depending on the UT inspection costs, more tanks may be examined.

- Visual examination of the SY101 instrument tree will be considered after the costs for UT inspection services are known.

- Tank wall inspections on six representative tanks for wall thinning and pitting by a commercial UT service supplier.

- Tank bottom and knuckle inspections on six representative tanks in four locations for wall thinning, pitting, and crack detection by a commercial UT service provider.

The estimated cost of this recommended alternative is $\$ 3 M$. The majority of the cost is for the UT service provider and the provider's support. The actual costs would be determined by the results of a procurement action with firm-fixed-price contract terms.

The recommended alternative makes compromises in schedule and data quality to attain a low project cost. An important part of achieving low project costs is the ability to obtain a performance-based contract.

The schedule may be compromised if the UT service provider fails to provide the examination data. The schedule would suffer because of the time required to obtain a new service provider and the time lost by the first service provider.

The data quality compromises are a reduction in the area examined at all of the critical locations on the tank wall and a reduction in the defect sizing accuracy. These compromises increase the program risk because they increase the chance of not detecting degradation. Also, if degradation is detected, the ability to increase the examination area and the ability to monitor changes in the degradation are limited.

These risks are considered acceptable for two reasons:

- The decrease in the examination area at critical tank wall locations is small and is compensated by the internal visual examinations

- If degradation is detected, equipment capabilities could be added to the commercial equipment or the DSTI could be put in service to provide the needed information.

Another risk is the response from Ecology to performing less examination than dictated by the established technical requirements. Ecology is relying on the TSIP to judge the adequacy of the tank integrity examinations. 


\subsection{SUMMARY}

Integrity assessments consist of design assessments and corrosion assessments. Design assessments have predicted, with some uncertainty, that the DSTs are expected to continue to perform without failure. Corrosion assessments are needed to confirm the prediction and are key to adequate performance of the TWRS "store waste" function.

Pitting corrosion, stress-corrosion cracking and uniform corrosion have been identified as the types of corrosion of concern in the DSTs. WHC, DOE, and Ecology have agreed that six DSTs will be examined and are representive of all DSTs with regard to adverse corrosion conditions. The bases for examining specific areas of the primary and secondary tanks have been identified and acceptance criteria are in place for evaluating the results of the examination.

Examination methods, including those existing and those under development, have been evaluated. A combination of visual and UT has been selected as the best alternative and the basis for the selection is provided.

Corrosion assessments require significant resources to complete. Costs, schedules, and data quality are factors that must be considered before committing significant resources to this effort. These factors have been considered in determining examination scope and methods and the type of equipment that has been identified as being capable of completing the corrosion assessment. Specific equipment is yet to be identified and is pending the availability of funds, agreed-schedules, and accepted levels of data quality.

\subsection{REFERENCES}

Abatt, F. G., 1996, Double-Shell Tank Useful Life Analysis, WHC-SD-WM-ER-556, Rev.0, ICF Kaiser Hanford Company, Richland, Washington.

Bandyopadhyay, K. K., 1994, Guidelines for Development of Structural Integrity Programs for DOE High-Level Waste Storage Tanks, Draft, Westinghouse Hanford Company, Richland, Washington.

Blackburn, L. D., and H. L. Benny, 1992, In-service Inspection of Double-Shell Tanks at the Hanford Site, WHC-EP-505, Westinghouse Hanford Company, Richland, Washington.

Divine, J. R., W. M. Bower, S. A. McPartland, R. P. Elmore, and D. W. Engle, 1983, Double-Shell Slurry Low Temperature Corrosion Tests, PNL-4727/UC-70, Pacific Northwest Laboratory, Richland, Washington.

Divine, J. R., and W. M. Bowen, 1984a, Tank Corrosion Study, High Temperature Corrosion Tests, Four-Month Evaluation, Pacific Northwest Laboratory, Richland, Washington. 
Divine, J. R., D. J. Bates, and W. M. Bowen, 1984b, Tank Corrosion Study High Temperature Corrosion Tests Eight-Month Evaluation, Pacific Northwest Laboratory, Richland, Washington.

Divine, J. R., D. J. Bates, and W. M. Bowen, 1984C, Tank Corrosion Study: High Temperature Corrosion Tests on Double-Shell Slurry and Future Purex Mixtures Twelve-Month Evaluation, Pacific Northwest Laboratory, Richland, Washington.

Divine, J. R., W. M. Bowen, D. B. Mackey, D. J. Bytes, and K. W. Pool, 1985, Prediction Equations For Corrosion Rates of A-537 and A-516 Steels in Double-Shell Slurry, Future Purex and Hanford Facilities Wastes, PNL-5488, Pacific Northwest Laboratory, Richland, Washington.

Ecology, EPA, and DOE, 1996, Hanford Federal Facility Agreement and Consent Order, as amended, Washington State Department of Ecology, U.S. Environmental Protection Agency, and U.S. Department of Energy, 01 ympia, Washington.

Harris, J., 1993a, Visual Examination Report for Tank Annuli at the 241-AP Tank Farm, WHC-SD-WM-RPT-077, West inghouse Hanford Company, Richland, Washington.

Harris, J., 1993b, Visual Examination Report for Tank Annuli at the 241-AY/AZ Tank Farm, WHC-SD-WM-RPT-078, Westinghouse Hanford Company, Rich 1 and, Washington.

Harris, J., 1993c, Visual Examination Report for Tank Annuli at the 241-SY Tank Farm, WHC-SD-WM-RPT-076, Westinghouse Hanford Company, Richland, Washington.

Jensen, C. E., 1995a, Multi-Function Waste Tank Facility Phase Out Basis, WHC-SD-W236A-ER-021, Westinghouse Hanford Company, Richland, Washington.

Jensen, C. E., 1995b, Acceptance Criteria for Non-Destructive Examination of Double-Shell Tanks, WHC-SD-WM-AP-036, West inghouse Hanford Company, Rich1 and, Washington.

Karwoski, W. J., 1992, Structural Integrity Evaluation of 241-AW Tank Farm Dangerous Waste Storage Tank Facilities, WHC-SD-WM-ER-126, Westinghouse Hanford Company, Richland, Washington.

Keibe1, G. R., 1996, Light Duty Utility Arm Baseline System Description, WHC-SD-TD-ER-005, Westinghouse Hanford Company, Richland, Washington.

Koreski, G. M., and J. N. Strode, 1995, Operational Waste Volume Projection, WHC-SD-WM-ER-029, Westinghouse Hanford Company, Richland, Washington.

Nelson, J. L., G. L. Edgemon, P.C. Oh 1, and J. R. Divine, Chem Met, Ltd., 1996, Evaluation of Alternatives for Upgrading Doub7e Shell Tank Corrosion Monitoring at Hanford, WHC-SD-WM-ER-538, Westinghouse Hanford Company, Richland, Washington. 
Pfluger, D. C., 1994a, Double-Shell Tank Ultrasonic Inspection Plan, WHC-SD-WM-AP-019, Westinghouse Hanford Company, Richland, Washington.

Pfluger, D. C., 1994b, Tank Waste Remediation System-Tank System Integrity Assessments Program P7 an, WHC-SD-WM-AP-017, Westinghouse Hanford Company, Richland, Washington.

Pfluger, D. C., 1995, Double-Shell Tank Ultrasonic Inspection Performance Specification, WHC-S-4108, Rev 2, Westinghouse Hanford Company, Richland, Washington.

Resource Conservation and Recovery Act of 1976, 42 USC 6901, et seq.

Schwenk, E. B., 1992, Tank Wall Measurement Technical Study and Specification, WHC-SD-W151-ES-002, Westinghouse Hanford Company, Richland, Washington.

Schwenk, E. B., 1995, Evaluation of Remaining Life of the Double-Shell Tank Waste Systems, WHC-SD-WM-ER-432, Westinghouse Hanford Company, Richland, Washington.

Schwenk, E. B., and K. V. Scott, 1996, Description of Double-Shell Tank Selection Criteria for Inspection, WHC-SD-WM-ER-529, Westinghouse Hanford Company, Richland, Washington.

Walter, E. J., 1992a, Visual Examination of Tank Annuli of the 241-AW Tank Farm, WHC-SD-WM-RPT-034, Westinghouse Hanford Company, Richland, Washington.

Walter, E. J., 1992b, Visual Examination of Tank Annuli of the 241-AN Tank Farm, WHC-SD-WM-RPT-061, Westinghouse Hanford Company, Richland, Washington.

Walter, E. J., 1995, Double-Shell Tank Waste System Assessment Status \& Schedule, WHC-SD-WM-ETP-153, Westinghouse Hanford Company, Richland, Washington.

WAC 173-303, 1993, "Dangerous Waste Regulations, "Washington Administrative Code, as amended. 
WHC-SD-WM-PD-047

Rev. 0

APPENDIX A

COST-BENEFIT EVALUATION

$A-j$ 
WHC-SD-WM-PD-047

Rev. 0

This page intentionally left blank. 
WHC-SD-WM-PD-047

Rev. 0

\section{APPENDIX A}

\section{COST-BENEFIT EVALUATION}

The Double-Shell Tank Integrity Examination in-Process Review identified the activities that are required to meet the integrity examination technical requirements. The amount of information that will be obtained by the identified activities ensures, with a high degree of confidence, that the results of the integrity examination of the tanks will be accurate. The cost of this accurate, high-confidence examination is $\$ 3.6 \mathrm{M}$.

The Tank Waste Remediation System (TWRS) annual funding planned for the entire integrity assessment scope in the multi-year program plan is $\$ 1 \mathrm{M}$. At this funding level, the integrity examination activities must be reduced in scope. To decide how many or to what extent each of the activities will be performed, we need to know the cost/benefit of each activity in the program and the cost/benefit of the overall integrity assessment program in relation to the other TWRS programs. This document provides an evaluation of the cost/benefit of the activities that could support the DST integrity examination program. The program's overall benefit relative to other TWRS programs is outside the scope of this document.

\section{COST}

The costs for performing the examination to the extent and degree described in Section 3.2 using the available equipment is described in Section 3.4 of the Double-She 71 Tank Integrity Examination in-Process Review. Higher risk strategies need to consider what information can be obtained that provides the best cost/benefit. Specific cost information will be presented later. The lowest cost for the most benefit is driven by what requires the least, and preferably no, equipment development and is available commercially as a complete service (vendor inspections of tanks with vendor-owned equipment) for several reasons. When equipment is not available, development is required, and costs are high. In addition, without available equipment, the buyer has difficulty finding alternative sources of equipment and examination services. The lack of competition pushes the cost higher by inhibiting the buyer's ability to obtain the service for a fixed price, thereby increasing the chance for costs to grow. Therefore, inspection services that are available and routinely used will have the lowest cost.

\section{BENEFIT}

The corrosion mechanisms of interest and where corrosion may be occurring have been thoroughly studied. These studies all agree on which corrosion mechanisms are important and where the corrosion is likely occurring (see Section 3.2). 
WHC-SD-WM-PD-047

Rev. 0

The relative merit of each inspection activity can be judged based on three important factors:

- The likelihood that the degradation is occurring. Determining the likelihood that the degradation is occurring is meant to determine which corrosion mechanism is most likely to occur, whether the corrosion is uniform, pitting, or stress-corrosion cracking, and where the corrosion is most likely to occur.

- The likelihood the activity will detect the degradation

- The relative consequences of the degradation.

The materials and corrosion engineers agree that the relative order for corrosion mechanisms is, from most to less likely, pitting, stress-corrosion cracking, and uniform corrosion. This consensus is based on the same limited data and the absence of tank failures that were mentioned in the main document. With respect to the location of the degradation, each activity combines what the inspection method can detect with the location at which the degradation is most likely to occur. Cracks are more likely to be at the high-stress tank knuckle-tank bottom region. Pitting is most likely to occur under deposits where the waste chemistry may be different from the bulk waste chemistry, such as under the solids on the bottom of the tank or under the solid waste precipitates on the side wall or at a waste interface (1iquidvapor or solids-liquid interface).

The likelihood of detecting degradation is good for each activity because each activity is designed to detect specific degradation. As with any in-service inspection program, the purpose of the inspections is to detect global degradation, not unique and localized degradation that may occur as the result of a fabrication defect. To obtain commercial equipment to detect degradation at a reasonable cost, the following compromises in the technical requirements are recommended:

- Reduce the tank waTl UT inspection area to the area directly below a 24-in.-diameter inspection riser. The inspected area is 5-in. wide and $35-\mathrm{ft}$ long. If a significant indication of wall thinning or pitting is evident, the inspected area can be increased by moving the equipment laterally up to $10 \mathrm{in}$. and repeating the vertical inspection pass or by entering a second inspection riser.

- Eliminate the requirement to size crack depths and detect only those cracks that are perpendicular to the highest stress region in the lower knuckle and are inside-surface-breaking cracks more than 0.2 in. deep. Retain the requirement to distinguish between an inside-surface crack and other defects (subsurface and outsidesurface-breaking defects). If crack detection is added to the tank wall inspection scope, only search for and detect those cracks that are perpendicular to the circumferential welds. Crack detection relies on a different and stronger signal echo than crack depth sizing and also requires fewer transducers. Eliminating depth sizing requirements may allow the inspection to be done without first cleaning the tank. This is a good compromise of technical requirements if no inside-surface-breaking 
cracks are present. If cracks are not present, the ability to size the crack depths has no value. If the crack is not open to the waste, it cannot grow by nitrate-stress-corrosion cracking and does not threaten the integrity of the tank. The length of the crack will be determined using the same method as used to detect the crack.

- Eliminate the requirement to inspect the portion of the lower knuckle that is at an elevation greater than $0.5 \mathrm{in}$. above the tank bottom. This should significantly simplify the equipment capabilities while still inspecting the high-stress region.

The consequence of degradation is ultimately a tank leak or rupture. of the three degradation mechanisms, pitting and cracking are expected to cause a tank leak before a tank rupture, giving time for corrective action. Uniform corrosion is not expected to give any warning before a tank ruptures.

There is no safety significance to a leak or a rupture (Jensen 1995b). A rupture would be more costly to recover from and more likely to result in waste reaching the soil. The consequence of a leak depends on where the leak occurs. A leak in the tank bottom will cause action to be taken to have the tank pumped out and add costs to the tank remediation and disposal effort. A leak above the maximum allowed waste level may have no consequence.

Comparing the examination activities with these factors suggest that the activities that provide the most benefit are the tank bottom examination for pits and the visual examination of the lowest section of both the removed equipment and the tank. Also important, but to a lessor degree, are the tank wall ultrasonic examinations on the lower part of the wall and the inspection for cracks in the tank knuckle-tank bottom region. Of least benefit are the examinations at or above the maximum-allowed-waste level.

\section{EVALUATION OF COST/BENEFIT}

From the preceding discussion, the lowest cost activity is determined by what equipment and service is commercially available. The exception to this conclusion is the camera systems used inside the tanks. Although these are not commercially available, TWRS has developed the equipment to support other programs. This equipment is available without development costs and, therefore, for the purpose of this document is considered commercially available.

The list of recommended activities and their estimated cost is shown in Table A-1. The better cost/benefit rated activities are listed first. 
Table A-1. Examination Activity Cost

\begin{tabular}{|l|r|}
\hline \multicolumn{1}{|c|}{ Activity } & \multicolumn{1}{|c|}{$\begin{array}{c}\text { Cost } \\
\text { (\$K) }\end{array}$} \\
\hline \hline Visual Examination of Equipment (2 items) & 80 \\
\hline Visual Examination of Tank Interior (3 tanks) & 110 \\
\hline Visual Examination of SY101 Instrument Tree & 205 \\
\hline Tank Wa11 UT Examination (6 tanks) & 1,100 \\
\hline Tank Knuckle/Bottom UT Examination (6 tanks) & $>1,100$ \\
\hline
\end{tabular}

The cost of the UT activities is high compared to the other activities because of the expected development costs. After development, the data obtained by the UT examinations have a lower cost-to-benefit ratio than the visual examination of the instrument tree. The suggested strategy is to obtain UT cost estimates before deciding to proceed with the instrument tree examination. 
DISTRIBUTION SHEET

\begin{tabular}{|c|c|c|c|c|c|}
\hline \multirow{2}{*}{$\begin{array}{l}\text { To } \\
\text { TWRS Environmental Compliance } \\
\text { Support Services }\end{array}$} & \multicolumn{3}{|l|}{ From } & \multicolumn{2}{|l|}{ Page 1 of 1} \\
\hline & \multicolumn{3}{|c|}{$\begin{array}{l}\text { TWRS Design Basis Equipment } \\
\text { Engineering }\end{array}$} & \multicolumn{2}{|c|}{ Date $05 / 8 / 96$} \\
\hline \multicolumn{4}{|l|}{ Project Title/Work Order } & \multicolumn{2}{|c|}{ EDT No. 613026} \\
\hline \multicolumn{4}{|c|}{$\begin{array}{l}\text { WHC-SD-WM-PD-047 } \\
\text { Double-She11 Tank Integrity Examination In-Process Review } \\
\text { IN1F31 }\end{array}$} & \multicolumn{2}{|l|}{ ECN No. N/A } \\
\hline Name & MSIN & $\begin{array}{l}\text { Text } \\
\text { With All } \\
\text { Attach. }\end{array}$ & Text Only & $\begin{array}{l}\text { Attach./ } \\
\text { Appendix } \\
\text { Only }\end{array}$ & $\begin{array}{l}\text { EDT/ECN } \\
\text { Only }\end{array}$ \\
\hline
\end{tabular}

D. Alison

J. J. Badden

L. D. Blackburn

J. F. Brown

R. A. Dodd

B. G. Erlandson

L. A. Garner

J. E. Geary

G. N. Hanson

T. S. Hundal

D. E. Jackson

W. W. Jenkins

L. J. JuTyk

W. C. Miller

R. J. Nicklas

P. C. Ohl

D. C. Pfluger (3)

G. F. Posakony

M. L. Ramsay

D. P. Reber

S. H. Rifaey

M. J. Royack

C. O. Ruud

E. B. Schwenk

K. V. Scott $(10)$

A. R. Sherwood

J. P. Sloughter

J. M. Thurman

J. E. Truax

E. J. Walter

Central Files (Orginal)

$\begin{array}{ll}\text { R1-51 } & X \\ \text { T4-07 } & X \\ \text { H5-53 } & X \\ \text { S5-03 } & X \\ \text { S5-07 } & X \\ \text { H6-20 } & X \\ \text { R2-36 } & X \\ \text { S5-07 } & X \\ \text { S5-05 } & X \\ \text { H5-52 } & X \\ \text { A5-15 } & X \\ \text { S2-24 } & X \\ \text { H5-56 } & X \\ \text { A2-34 } & X \\ \text { R1-43 } & X \\ \text { R1-30 } & X \\ \text { H5-52 } & X \\ \text { K5-26 } & X \\ \text { S7-54 } & X \\ \text { T4-07 } & X \\ \text { S1-57 } & X \\ \text { S7-54 } & X \\ \text { S7-54 } & X \\ \text { H5-52 } & X \\ \text { H5-52 } & X \\ \text { H6-20 } & X \\ \text { R2-54 } & X \\ \text { R1-51 } & X \\ \text { R2-50 } & X \\ \text { H5-52 } & X \\ \text { A3-88 } & X \\ & \end{array}$

Off-Site Distribution

C. Paul Warbington

Roy $F$. Weston, Inc.

Lakewood, CO 80228-1842 